\title{
POLÍTICA, ESTADO E DEMOCRACIA: COMO A ARGENTINA ALCANÇA A MATURIDADE INSTITUCIONAL SOB A LUZ DE PAULO FREIRE
}

\author{
Plínio Antônio Britto Gentil ${ }^{1}$ \\ Ana Paula Jorge ${ }^{2}$
}

\section{RESUMO}

Esta pesquisa aproxima os princípios educacionais de Paulo Freire com relato, obtido por pesquisa de campo e bibliográfica, de como a Argentina enfrenta o terrorismo de Estado, sistemática violação de direitos humanos, patrocinada por sua mais recente ditadura. Utilizando saberes da principiologia freireana, que considera toda educação uma ação política, o povo e as instituições daquele país superaram uma fase de identificação com o opressor e de falta de crença em si mesmos, alcançando um estágio de amadurecimento que lhes possibilita processar e julgar criminalmente os violadores, promovendo dessa forma um reencontro do Estado com a nação, revelando maturidade institucional.

Palavras-chave: Maturidade política; Estado e Democracia; Verdade, Memória e Justiça; Argentina; Paulo Freire;

\section{POLICY, STATE AND DEMOCRACY: HOW ARGENTINA REACHES INSTITUTIONAL MATURITY UNDER PAULO FREIRE'S LIGHT}

\begin{abstract}
This research brings together Paulo Freire's educational principles with an account, obtained from field and bibliographic research, of how Argentina confronts state terrorism, a systematic violation of human rights, sponsored by its most recent dictatorship. Using knowledge of Freire's princiology, which considers all education a political action, the people and institutions of that country have overcome a phase of identification with the oppressor and lack of belief in themselves, reaching a stage of maturity that allows them to prosecute and prosecute criminally. violators, thus promoting a reunion of the state with the nation, revealing institutional maturity.
\end{abstract}

Keywords: Political maturity; State and Democracy; Truth, Memory and Justice; Argentina; Paulo Freire;

\section{INTRODUÇÃO}

Este trabalho propõe-se a fazer uma aproximação entre os princípios pedagógicos desenvolvidos por uma vertente humanista da educação, notadamente por Paulo Freire, e o despertar de uma consciência segundo a qual somente a concretização da justiça é capaz de

\footnotetext{
${ }^{1}$ Mestre em Direito (Unitoledo-Araçatuba-SP). Professora universitária de Direito Penal e Processo Penal. Analista judiciária federal. Autora de obra de Direito Penal.

${ }^{2}$ Doutor em Direito das Relações Sociais (PUC-SP) e em Fundamentos da Educação (UFSCar), pesquisador em Educação e Direito (UFSCar), professor de Direito (graduação e mestrado). Procurador de justiça no MPSP. Autor de obras de Educação e Direito.
} 
assegurar um estado duradouro de paz. Uma tal situação é perceptível na realidade da nação argentina no que se refere à apuração dos crimes de sua última ditadura militar (1976-1983) e à resposta penal que se tem dado às violações de direitos humanos praticadas naquele período.

A educação, para Freire, é um ato político: é impossível educar sem engajar-se, uma vez que educador e educando intercambiam seus próprios elementos culturais durante o processo de ensino-aprendizagem, forçosamente alcançando um estágio de percepção das conexões que existem em torno de suas vidas, que no mais das vezes fazem ambos reféns de relações de poder que antes não conseguiam visualizar. É justamente essa compreensão da dimensão política da vida em sociedade que leva ao descortino de situações em que interesses dominantes, mas dissimulados pela bandeira da universalidade, podem oprimir e massacrar os dominados. Um caso de dominação dessa natureza fez-se visível no período em que a ditadura militar na Argentina, possivelmente a mais sanguinária do cone sul no último quarto do século XX, exerceu seu inconstrastável poder sobre a nação, procurando eliminar qualquer tipo de oposição, em prol da garantia de um modelo econômico de extrato liberal com hegemonia do capital internacional - empresarial ou financeiro.

A escolha da República Argentina como paradigma dá-se tendo em vista variados fatores: sua relevância geopolítica no continente americano, sua proximidade física e cultural com o Brasil, a conhecida integração entre os povos argentino e brasileiro e o fato de um dos autores ter sido convidado, no ano de 2013, pelo Instituto Espacio para la Memoria, de Buenos Aires, para conhecer a experiência de coleta de dados, preservação da memória, difusão de informações e alimentação de procedimentos judiciais promovida por esta e outras instituições argentinas direcionadas à concretização de três objetivos: a verdade, a memória e a justiça relacionadas às violações de direitos humanos praticadas por sua ditadura militar. Dessa visita provém boa parte dos elementos utilizados nesta pesquisa. Deve-se também à atividade dos autores como pesquisadores e autores de publicações sobre a educação freireana, ações que os têm levado à participação em congressos com essa temática, como o Encuentro Presencia de Paulo Freire (anos de 2006 e 2010, em Cienfuegos, Cuba) e I Seminario Internacional Paulo Freire (2013, em Buenos Aires, Argentina).

O que o trabalho pretende é mostrar aspectos de como a Argentina enfrenta a realidade de uma nação que emergiu de um tempo de brutalidade oficial. Ao fazê-lo, o trabalho procurará demonstrar como o despertar de tal consciência política é resultado de um processo de aprendizagem política em que seus sujeitos - na verdade, o povo como tal e os agentes do Estado - fundindo suas experiências havidas num período de desumanidade estatal, alcançaram a compreensão de que uma verdadeira reconciliação do Estado com a nação somente seria plena se, além da obtenção da verdade e a preservação da memória histórica, também se buscasse a realização da justiça, aplicando as sanções do direito penal aos responsáveis.

\section{O TERRORISMO DE ESTADO DA DITADURA ARGENTINA}

Havendo passado por uma ditadura militar devastadora, a Argentina experimenta atualmente uma prática política e jurídica que se caracteriza por um decidido enfrentamento dos crimes cometidos por agentes da repressão. O período mais crítico dessa repressão ocorreu durante a ditadura militar, ou o chamado Proceso de Reorganizacion Nacional (1976 a 1983), mas também inclui abusos praticados ainda antes da tomada do poder pelos golpistas, quando o governo da presidente María Estela Martinez de Perón já dava mostras de fraqueza. 
Sua postura vacilante ${ }^{3}$, malgrado a base popular do governo, permitia, graças à inoperância política da governante, que o próprio Estado apoiasse atividades terroristas voltadas contra setores progressistas desejosos de aprofundar os compromissos sociais da administração do país.

O golpe, como se dava no mesmo período em outros países latino-americanos, foi gestado pelos setores comprometidos com o grande capital, nacional e internacional, utilizando mão de obra armada, oriunda de segmentos doutrinados segundo premissas do capitalismo mais atrasado e agressivo. Graças a esse conluio, promovem-no e dele se beneficiam segmentos de alta posição da iniciativa privada. Essa percepção é, às vezes, tardia, como anota o Diário del 24 de marzo ${ }^{4}$, de março de 2013 (p. 5):

Somente alguns setores políticos enfatizaram prematuramente que o caráter do golpe de 24 de março de 1976 era cívico-militar e que, a despeito de serem as Forças Armadas que detinham o poder, os principais beneficiários do denominado "Processo de Reorganização Nacional" eram os setores concentrados de poder econômicofinanceiro e outros poderes fáticos. ${ }^{5}$

Sucederam-se chefes militares no poder desde o golpe de 24 de março de 1976: Jorge Videla, Roberto Viola, Leopoldo Galtieri, Reynaldo Bignone. O regime que se instala, autoproclamado Proceso de Reorganizacion Nacional, promove a caça de opositores, por serem de esquerda ou por serem simplesmente opositores. Age à margem da lei, sendo numericamente inexpressivos os casos de perseguidos políticos processados regularmente por práticas contra o governo militar.

Usa-se largamente naquele país a expressão terrorismo de Estado para designar a ação ilegal e abusiva dos organismos de repressão política, que atuaram no período da ditadura militar. Significa o uso sistemático, sob o patrocínio do Estado, de procedimentos tendentes a impor medo à população e obter, por condutas ilícitas, resultados que não se obteriam de outra maneira. O terrorismo de Estado amedronta, tortura e comete crimes, geralmente violentos. É o mesmo terrorismo em seu sentido comum, só que praticado por agentes do Estado, ou por ele apoiados, e por alegadas razões de Estado. Na Argentina, "o terrorismo de Estado teve sua trágica apoteose no período 1976-1983” (Bayer, 2010: 25).

O saldo do terror na Argentina é significativo. Estima-se que houve em torno de quinhentos centros clandestinos de detenção no país. Para tais lugares eram levados os inimigos, depois de sequestrados. Lá permaneciam sem que dessa prisão alguma notícia se desse, quer a familiares, quer à autoridade judicial. Seguiam-se sessões de interrogatórios, ornados por métodos ilegais de coação, e o tempo de permanência do preso não era determinado. Objetivava-se que oferecesse informações acerca de sua possível conexão com grupos de oposição ao governo, ou de contestação do modelo sócio-econômico, fossem eles trabalhadores, profissionais liberais, adversários militares, parlamentares ou estudantes. $\mathrm{O}$

\footnotetext{
${ }^{3}$ A presidente, conhecida por Isabelita, fora eleita vice-presidente na chapa encabeçada por seu marido, Juan Domingo Perón, carismático líder e ex-presidente, que voltara do exílio, tendo assumido o governo quando este morreu durante o exercício do mandato. Isabelita confessadamente não tinha vivência política para posto de tal envergadura, nem esperava tanto.

${ }^{4} \mathrm{O}$ trabalho opta por não traduzir certos nomes ou expressões, por vezes frases inteiras. A opção deve-se ao fato de que, em geral, é viável compreender os seus termos em espanhol e que, assim mantidos no texto, haverá momentos em que serão mais expressivos e contundentes se lidos no original.

${ }^{5}$ Trad. dos autores.
} 
preso podia ficar ali por dias ou meses, incomunicável. Há relatos de quem disse saber qual o dia da semana porque, normalmente aos domingos, a torcida do Club Atletico Boca Juniors passava pela rua cantando, rumo ao estádio. Podia ocorrer a liberação de alguém, uma vez apurado que não tinha ligação com a política adversária. Muitos outros eram mortos.

Para matar não havia um método específico. Eram entretanto comuns os falsos "confrontos com a polícia", dos quais inevitavelmente resultava a morte dos condenados como inimigos do regime, ou subversivos.

Alguns desses ex-centros clandestinos de detenção ficaram famosos. Um deles funcionava na conhecida ESMA, sigla para a Escuela de Mecânica de la Armada, outro no Club Atletico, nos locais conhecidos como Olimpo, Campo de Mayo, mais um numa antiga residência situada na rua Virrey Cevallos, n. 630, outro ainda numa antiga oficina de veículos (Automotores Orletti), todos na cidade de Buenos Aires, além de outros tantos.

O da Rua Virrey Cevallos converteu-se numa espécie de museu-escola, para onde são levadas, mediante agendamento, turmas de estudantes, desde 12 anos de idade, que recebem explicações históricas sobre a ditadura militar e seus crimes, bem como sobre o funcionamento daquele antigo centro de detenção. Pode haver exibição de filmes. Os estudantes, ao final, fazem dramatizações e apresentam algumas manifestações artísticas, como desenhos, pinturas e esculturas, tudo relacionado com os relatos acerca da repressão política. Também os professores são envolvidos nesse trabalho de reconstrução histórica, pois "ainda é necessário informar corretamente os educadores sobre o passado recente do país, a fim de que, o conhecendo e o repassando a seus alunos, se possa assegurar que tal história não se repita", afirmou o administrador do local, Osvaldo López. ${ }^{6}$

Calcula-se um número de mortos e desaparecidos que beira trinta mil pessoas. Segundo o procurador da unidade de Direitos Humanos do Ministério Público de Buenos Aires, Jorge Auat, "são raras as famílias argentinas que não tenham, direta ou indiretamente, tido contato com alguma forma de perseguição política durante a ditadura": se não um parente, pelo menos um conhecido, um vizinho, um amigo foi vítima do terrorismo de Estado. $^{7}$

Em mãos de governos militares do mesmo cariz, o Uruguai e o Brasil, especialmente, cooperaram com a repressão argentina para a localização e o repatriamento de foragidos políticos, com o fim de serem justiçados pelo terrorismo de Estado de seus respectivos países, como sucedeu a várias dessas vítimas, capturadas fora do território argentino. Aliás não é novidade alguma a existência do famigerado Plano Condor, envolvendo governos militares ditatoriais da América do Sul nesse período. Dele assim fala uma publicação conjunta de Asamblea Permanente por los Derechos Humanos e Instituto Espacio para la Memoria (3 ed., p. 26), intitulada Memoria y dictadura:

A Operação Condor foi uma ação de coordenação internacional da repressão, levada a cabo pelos governos ditatoriais do Cone Sul durante os anos 60 e 70. Foi o espelho sinistro de outros pactos de contra-insurgência, como a Operação Fênix, levada adiante na Ásia pela CIA, em meados dos anos 60. A Operação Condor foi uma destas ações contra-insurgentes, que se distinguiu das demais pela seletividade das vítimas, especialmente em seus primeiros golpes.

\footnotetext{
${ }^{6}$ Depoimento ao autor, em 18/abr./2013.

${ }^{7}$ Depoimento ao autor, em 19/abr./2013.
} 
Entre os sócios deste pacto encontramos Augusto Pinochet (Chile), Hugo Banzer (Bolívia), Alfredo Stroessner (Paraguai), Aparício Méndez (Uruguai), Francisco Morales Bermúdez (Peru) e Emílio Garrastazu Médici (Brasil). ${ }^{8}$

José Luis Méndez Méndez (2011: 68), jurista e pesquisador especialmente dedicado a este assunto, frisa:

A Operação Condor contratou delinquentes comuns que introduziu na repressão multinacional: eram os chamados "inorgânicos", formados em esquadrões da morte, que na Argentina se chamavam patotas; uma das mais famosas por seus crimes e desmandos foi a de Aníbal Gordon, que operou inclusive quando já restabelecida a democracia. ${ }^{9}$

Muitos dos desaparecimentos e mortes - há desaparecidos que ainda não foram identificados, daí figurarem como tal e não como mortos - ocorreram com requinte: sabe-se hoje, comprovadamente, da prática de sedar prisioneiros sequestrados e atirá-los de avião sobre o rio da Prata. Ossadas foram encontradas - e continuam a sê-lo - no fundo do rio, onde também se localizaram corpos ocultos dentro de barris. A identificação é um procedimento de sofisticada técnica e nisso tem havido empenho dos órgãos encarregados da apuração dos fatos. Há, em primeiro lugar, um trabalho de comparação dos restos de acordo com o local onde foram encontrados e o centro de detenção mais próximo, ou o correspondente à ocultação dos cadáveres no sítio de sua localização.

Há registro de centenas de casos de bebês, filhos das vítimas, que foram encaminhados para adoção ilegal por parte dos agentes da repressão, incluindo militares de elevada patente. Trata-se do que se denomina apropriação de crianças. Hoje dezenas desses casos foram elucidados e as reações dos "adotados" é variável, "dependendo do tipo de tratamento que tiveram dos seus 'pais adotivos': alguns os rejeitam, outros não, com alguns também surge um certo tipo de estranhamento", comentou Alba Pereyra Lanzilotto, diretora pedagógica do Instituto da Memória, de Buenos Aires. ${ }^{10}$

\section{A BUSCA POR JUSTIÇA}

Tendo o país retornado ao regime de legalidade, com a eleição de um presidente civil que começou a governar no final do ano de $1983^{11}$, pouco a pouco se desenvolve a construção de uma teoria acerca da necessidade de apurar e aplicar o direito vigente em relação aos casos de violações de direitos praticadas no período que se encerrava. Aparentemente havia um óbice jurídico: as leis editadas num clima de acomodação com o poder militar que se afastava haviam sido imaginadas para livrar de problemas os que tinham atuado na repressão política, em outras palavras, os torturadores, sequestradores, estupradores e homicidas que agiram apoiados pelos governos militares.

Assim é que, segundo lembra Camila Vicenci Fernandes (s/d),

\footnotetext{
${ }^{8}$ Trad. dos autores.

${ }^{9}$ Trad. dos autores.

${ }^{10}$ Depoimento ao autor, em 20/abr./2013.

11 Trata-se de Raúl Ricardo Alfonsín.
} 
Em 1986, editou-se a chamada "Lei Ponto Final" (Lei 23.492/86), que determinava a extinção das ações penais por participação nos atos de forma violenta de ação política (BUCHANAN, 1987) e, em seguida, foi editada a "Lei Obediência Devida" (Lei 23.521/87) que extinguia a punibilidade dos crimes perpetrados [...] sob a alegação de que os militares agiram em obediência devida, sob coerção de autoridades superiores [...]. Finalmente, o então presidente argentino Carlos Menem concedeu ainda uma série de indultos aos militares já condenados (BARROS, 2003) [...].

Todavia, em 2003, durante o governo de Nestor Kirchner, foram revogadas essas leis de anistia de 1986 e 1987 e mesmo os indultos concedidos por Carlos Menem não puderam subsistir ante o posicionamento firme da Suprema Corte, em 2005. De novo anota aquela autora:

O primeiro passo foi dado em 2003 com a aprovação, pelo Congresso argentino, de uma lei que revogava as leis Ponto Final e Obediência Devida. Em 2005, a Suprema Corte argentina decidiu que as leis de anistia são inconstitucionais, declarando-as nulas.

Desde então o judiciário argentino tem recebido denúncias de violações de direitos humanos cometidas pelos agentes da repressão e os vem processando regularmente, de acordo com as leis penais vigentes. A publicação Memoria y dictadura ${ }^{12}$ aponta o início dessas atividades judiciais:

O primeiro julgamento após a decisão da Corte Suprema de Justiça da Nação, em 2005, começou em junho de 2006 no Tribunal Oral Federal n. 1 de La Plata, onde foi julgado, entre outros, Miguel Osvaldo Etchecolatz, ex-Diretor Geral de Investigações da Polícia portenha, que foi considerado culpado de seis homicídios ocorridos durante a ditadura militar, pelos quais foi condenado a prisão perpétua. ${ }^{13}$

Estima-se que existam cerca de oitocentos processos criminais dessa natureza, tendo havido em torno de duzentas e oitenta condenações. Para Osvaldo López, do ex-centro Virrey Cevallos, "é um número apenas simbólico" ", mas que serve para demarcar a posição da justiça do país quanto à questão dos torturadores.

Simbólicas ou não, as condenações mostram-se expressivas em relação à estatura político-militar de alguns condenados: nada menos que dois ex-presidentes do regime militar, Jorge Videla e Reynaldo Bignone, foram apenados com prisão perpétua; o primeiro morreu na prisão, cumprindo pena, em 2013. A Internet está repleta de filmes, postados no sítio Youtube, exibindo as sessões públicas do judiciário argentino em que tais condenações foram proferidas, sob ovação popular. Há também notícia de precedente judicial considerando como

\footnotetext{
12 Op. cit.

${ }^{13}$ P. 64. Trad. dos autores.

${ }^{14}$ Depoimento ao autor, em 18/abr./2013.
} 
genocídio alguns crimes praticados por torturadores. ${ }^{15}$ De toda sorte, um dos entendimentos que têm justificado a atuação da justiça criminal nesses casos é o de que se trata de delitos contra a humanidade, que são declarados imprescritíveis por tratado internacional. ${ }^{16}$

Outro fato importante, que garante a atribuição da justiça penal comum sobre a ação dos torturadores, foi a revogação, em 2008, de dispositivos do Código Penal Militar. As sessões de julgamento são públicas e a mídia informativa divulga semanalmente seus resultados.

Aqueles setores da sociedade civil, que ajudaram a gestar o golpe e depois se aproveitaram de suas vantagens, tendo prestado colaboração preciosa a seus desígnios e a seus executores fardados, atualmente enfrentam a apuração de suas responsabilidades. Disso o Diário del 24 de marzo registra:

Quanto à responsabilidade criminal, a justiça neste período está avançando sobre outros agentes sociais, mais além do setor castrense. Podem-se mencionar como exemplos as causas judiciais que envolvem empresas (Ledesma, Astarsa, Loma Negra, Mercedes Benz, Ford, Papel Prensa, Acindar [...], entre outras). À medida que avança a investigação penal e as denúncias, vão se somando outros casos. A maioria dessas causas focaliza a implicação das empresas na entrega às forças armadas e de segurança de listas de trabalhadores integrantes de comissões internas e haver facilitado veículos, dinheiro e inclusive espaços físicos para funcionamento de centros clandestinos de detenção. $^{17}$

Tudo indica que uma autêntica reconciliação nacional, algo como o reencontro da nação com o Estado, de acordo com a consciência média de esclarecidos setores do universo jurídico, político e cultural da Argentina, passa necessariamente pela aplicação da lei criminal aos agentes da repressão patrocinada pelos governos militares. "Quanto aos crimes da ditadura, não basta apurar a verdade e preservar a sua memória. Para que estas se mantenham é preciso fazer justiça. O tripé verdade-memória-justiça não pode ser visto separadamente". ${ }^{18}$

\section{A BUSCA PELA VERDADE E PRESERVAÇÃO DA MEMÓRIA}

Está bem claro que a atual postura da comunidade jurídica argentina não é apenas obra dos legisladores ou dos juízes: tanto a revogação das leis de anistia quanto a posição da jurisprudência, considerando aqueles delitos como crimes contra a humanidade e assim desprezando o argumento da prescrição, ou da anistia concedida, apóiam-se na edificação de uma verdadeira doutrina, difundida entre a opinião pública mais esclarecida, no sentido de que é necessário punir os violadores de direitos como requisito para uma verdadeira conciliação nacional.

É verdade que para isso colaborou a postura da Corte Interamericana de Direitos Humanos, a qual, já desde 1999, proferia decisões favoráveis a petições individuais, nas quais

\footnotetext{
${ }^{15}$ Segundo Elizabeth Victoria Gómez Alcorta, professora de Direito Penal da Universidade de Buenos Aires e diretora do IEM. Depoimento ao autor, em 19/abr./2013.

${ }^{16}$ O Estatuto de Roma do Tribunal Penal Internacional, artigo 29.

${ }^{17}$ Op. cit.: 5. Trad. dos autores.

${ }^{18}$ Osvaldo López. Depoimento ao autor, em 18/abr./2013.
} 
reconhecia o acesso dos familiares à verdade em relação a seus parentes desaparecidos, como foi o caso de Carmen Lapacó, que ficou conhecido.

Há iniciativas por todo o país tendentes a recuperar a memória do período, obtendo informações de toda natureza acerca das violações de direitos praticadas contra opositores políticos do regime militar. Essas informações subsidiam inquéritos e processos judiciais e fazem prova contra os autores, bem como dos crimes e de suas circunstâncias.

Um dos exemplos de órgão público voltado para a preservação da memória e a obtenção de elementos que subsidiem processos judiciais é o Instituto Espacio para la Memoria (IEM), criado por lei da Província de Buenos Aires. Edita publicações sobre o tema, inclusive um Manual para las víctimas y testigos em causas vinculadas al terrorismo de Estado, além de promover reuniões e aulas para esclarecimento de estudantes e professores.

Outro é o projeto que culminou com a criação do Parque de la Memoria, na capital do país. Trata-se de um parque de grande extensão, localizado na margem do rio da Prata, nos arredores do bairro de Palermo, em Buenos Aires. Existem esculturas, área verde gramada e uma longa calçada de passeio, acompanhando o traçado do rio. A um certo ponto se encontram paredes de alvenaria curvas e acinzentadas, nas quais estão esculpidos, em tabletes de pedra, nomes das pessoas desaparecidas identificadas, com suas idades e as datas prováveis de sua morte. Junto aos nomes de algumas vítimas do sexo feminino consta o fato de estarem grávidas. Há um salão de eventos, destinado a exposições e cursos, contando com uma biblioteca. Chama a atenção, ao longo do caminho calçado que margeia o rio uma extensa fileira de "sinais de trânsito", cada qual contendo a indicação de um fato, ou uma situação relacionada com os crimes da repressão política. Assim, vêem-se "sinais" de assassinos empunhando armas contra um indivíduo desarmado, de um tanque de guerra com um \$ estampado, de um veículo Falcon, da Ford, utilizado pelos repressores, de um símbolo da Copa do Mundo de 1978 (ano em que a repressão atuava a pleno vapor), de um mapa da América do Sul contendo datas da instauração das ditaduras militares nos respectivos países etc. O lugar é aberto ao público e visitado por nacionais e estrangeiros, incluindo grupos de estudantes.

A explicação histórica para a infestação de ditaduras militares de direita em praticamente toda a América do Sul, a partir da segunda metade do século XX, vem resumidamente exposta em alguns desses "sinais de trânsito" do Parque da Memória. Interessa verificar:

Entre os anos de 1950 e 1975 os militares latino-americanos foram adestrados em diferentes instituições educativas militares norteamericanas, como a "Escola das Américas", no Canal do Panamá. Ali se ministraram cursos sobre tortura, interrogatórios, inteligência e treinamento militar contra insurgentes. O objetivo era proteger os interesses norte-americanos no continente e intervir naqueles países cujos movimentos políticos ou situação de insurgência constituíssem um obstáculo para o avanço de seus propósitos.

Para poder implantar um novo modelo econômico-social foi necessário aplicar um plano repressivo sistemático que destruísse as formas de organização política, laços sociais e relações solidárias que estavam sendo gestadas. O marco e suporte ideológico deste plano esteve constituído pela chamada "Doutrina de Segurança Nacional", 
que trouxe a justificação (desculpa) mais apropriada para esse contexto histórico. A Doutrina de Segurança Nacional foi elaborada pelo Pentágono (EEUU) e aplicada em toda a América Latina. O centro da Doutrina está estabelecido na defesa da "segurança da Nação", que se encontraria ameaçada permanentemente pela infiltração de elementos que buscariam a destruição do "modo de vida democrático" e de nossa "tradição ocidental e cristã". Sob este postulado se procedeu ao extermínio de toda forma de resistência na América Latina.

Merece, ainda, registro uma iniciativa não oficial levada a cabo pela entidade denominada Coordinadora Barrios X Memória y Justicia. Reconhecendo a dificuldade em comprovar judicialmente todas as violações de direitos humanos $\mathrm{e}$ promover as responsabilidades, civis e criminais, dos transgressores, organizou-se um núcleo de ação que, levantando dados de vítimas do regime e tencionando deixar publicamente registrados aspectos de suas vidas, tem providenciado o assentamento de lajotas, com a inscrição de seus nomes, em vias públicas de Buenos Aires, em pisos e paredes, de tal forma que sejam vistas e lidas por quantos ali circulam. E elas ali ficam, cimentadas.

Tal entidade já editou obra em dois volumes, intitulada Baldosas X la memória ${ }^{19}$, que retrata fotograficamente algumas dessas inscrições. Veja-se, por exemplo, como consta do segundo volume ${ }^{20}$, lajota assentada no bairro de Balvanera:

Aqui vivió y fue secuestrada Maria del Carmen Serrano, militante popular, detenida, desaparecida, por el terrorismo de Estado. 21/06/1977. Barrios X Memória y Justicia (p. 51).

Ou esta outra, no piso de uma calçada, em San Telmo:

Aqui vivió Elisabeth Kasemann (Liszy), militante popular, detenida, desaparecida (8-3-77) y asesinada (23-4-77), por el terrorismo de Estado. No olvidamos. No perdonamos. Barrios por Memoria y Justicia (p. 151).

Cuida-se de uma iniciativa que se mostra capaz de assegurar a perpetuação e a publicidade de atos de violação que não se pretende ver esquecidos nem repetidos. Ter consistido em uma ação consideravelmente divulgada e, ademais, ter o assentamento das inscrições sido feito ante o afluxo de expressivo número de pessoas, parece garantir a permanência das lajotas em seus lugares e o apelo constante da lembrança das vítimas.

Parece inegável a disposição dos argentinos em cobrar satisfações por abusos do Estado. Após grave crise econômica que atingiu o país no ano de 2001, os panelaços e as manifestações populares ${ }^{21}$ criaram um clima de constrangimento para o presidente Fernando de la Rúa, que, ante a negativa do Partido Justicialista (de base popular) em dividir com ele o governo do país, renunciou, tendo início uma fase de reciclagem da econo mia, das instituições

\footnotetext{
${ }^{19} \mathrm{O}$ termo baldosa significa lajota.

${ }^{20}$ Dispensa-se a tradução.

${ }^{21}$ Bando de ladrones, devuelvan nuestros dolares, dizia uma faixa exibida numa dessas manifestações de rua, protestando contra um confisco de depósitos bancários em dólares.
} 
e da política em geral, o que mais tarde levaria a uma radical reforma do judiciário. Nessa fase foi que o então presidente Nestor Kirchner (2003-2007), já tendo ordenado para que não constassem dos prédios militares os retratos daqueles chefes tidos por responsáveis pelas violações de direitos na ditadura, certa vez em visita a um colégio militar, em cerimônia pública e filmada, deparando-se, enquanto percorria os corredores, com tais quadros, mandou ao diretor do colégio que naquele mesmo instante os retirasse. Deu-se então um episódio constrangedor, algo entre o cômico e o grotesco: todo o público viu e a TV filmou aquele militar de alta patente, fardado, subindo numa banqueta e retirando, um a um, os retratos proscritos, entre os quais o do ex-presidente Jorge Videla. O episódio consta de uma gravação postada no Youtube, que já se tornou mundialmente conhecida.

Kirchner foi, mais tarde, aplaudido por isso. O amparo popular às atitudes governamentais de exigir satisfações da parte dos violadores de direitos parece fundamental para legitimar tais atitudes. Esse apoio renova-se diante de cada oportunidade. Numa delas, fez-se o velório dos restos de uma professora. A cerimônia aconteceria nas dependências de uma escola de ensino médio vinculada à Universidade de Buenos Aires (UBA), onde ela lecionava. Mesmo se tratando de uma morte ocorrida havia décadas, o comparecimento de pessoas foi enorme. Defronte a essa mesma escola, situada na rua Marcelo T. de Alvear, em Buenos Aires, o já mencionado grupo Barrios X Memoria y Justicia fez instalar nada menos do que seis baldosas (lajotas), delas constando os nomes de professores e alunos da instituição, vitimados pela repressão política da ditadura. Aqui enseñaron... e segue-se uma lista de nomes; Aqui estudiaron... segue-se outra. Cimentadas no chão da calçada, na porta de entrada da escola, reverenciadas e irremovíveis, parecem tender à eternidade.

O desejo de não esquecer aparece também no calendário do país: o dia 24 de março, data do golpe militar de 1976, é comemorativo. Em agosto de 2002, o Congresso promulgou lei (n. 25.633), qualificando-o como Dia Nacional da Memória pela Verdade e Justiça. Em 2005, por ato do Poder Executivo, a data foi considerada feriado nacional, portanto sem trabalho nem aulas. O objetivo de homenagear as vítimas foi contestado por alguns, frente à eventualidade de, graças ao feriado, dar-se a impressão de ser um dia de festa, ante o que o governo sustentou que "não há possibilidade de que algum docente possa ignorar o fato".22

O mesmo desejo - aliado a uma perene e interminável busca por notícias de desaparecidos e por justiça - é visível na rotina, há décadas repetida, das Madres e das Abuelas de Plaza de Mayo. Com lenços brancos na cabeça, às quintas-feiras, dão voltas, em grupo, na Praça de Maio, em frente à Casa Rosada, sede do governo da república, reivindicando sempre a mesma coisa. São em número cada vez menor, pois o tempo cobra o seu preço, e caminham cada vez mais devagar, porque já cansadas, mas lá estão, religiosamente. E sempre caminhando, pois já se acostumaram a caminhar, como no tempo da ditadura, quando a repressão não lhes permitia que ficassem ali paradas, dando-lhes ordem para circular.

Como compreender a verdadeira dimensão do terrorismo de Estado, quando o país emergiu da ditadura e começou a procurar um caminho de estabilidade e de paz? Como chegar a um ponto de conciliação da nação com o Estado, o mesmo que destroçara famílias e que parecia propenso ao esquecimento das violações praticadas? Por meio de que processo de aprendizagem logrou a sociedade argentina chegar ao ponto de maturidade que lhe permite passar-se a limpo e, sem receios nem subterfúgios, responsabilizar legalmente os que the impuseram tamanho sofrimento?

\footnotetext{
${ }^{22}$ Fonte: Wikipedia.
} 
Nesse passo, é oportuno deitar os olhos sobre o caminho traçado por Paulo Freire.

\section{OS PRINCÍPIOS DA EDUCAÇÃO FREIREANA}

A base principiológica da educação, para Freire, assenta-se em que educar significa proporcionar ao sujeito um distanciamento do objeto do conhecimento de maneira tal que seja capaz de construir conceitos próprios em relação a este e relacioná-lo com situações de sua vida real. Ao fazê-lo estará problematizando aquela situação e a relacionando com um círculo situacional mais amplo, num processo que o fará compreender sua inserção no seu universo vivencial e as relações sociais que condicionam seu comportamento, atitudes e modos de interpretar o mundo. A relação do professor com os alunos é horizontal e o objeto do conhecimento coloca-se entre eles, servindo de tema para um diálogo professor-alunos e ambos os lados aprendem com a experiência do outro.

De outro lado, como lembra Francisco Weffort, em prefácio para a décima sexta edição de Educação como prática da liberdade ${ }^{23}$, falando mais diretamente do programa de alfabetização e da liberdade como método:

A visão da liberdade tem nesta pedagogia uma posição de relevo. É a matriz que atribui sentido a uma prática educativa que só pode alcançar efetividade e eficácia na medida da participação livre e crítica dos educandos. [...] O coordenador, quase sempre um jovem, sabe que não exerce as funções de "professor" e que o diálogo é condição essencial de sua tarefa, "a de coordenar, jamais influir ou impor".

O objetivo imediato do professor, ou coordenador, é possibilitar a abstração dos discípulos. "Quando os alunos chegam à universidade, sua experiência de linguagem é, possivelmente, muito mais a experiência de definir o concreto de sua existência e não uma experiência de dançar com os conceitos por si mesmos", diz Freire, em diálogo com Ira Shor, tornado livro ${ }^{24}$. "Os trabalhadores têm uma linguagem muito direta, assim como uma vida que é muito direta", continua. "Mas se estão entrando na universidade, precisam aprender a usar os conceitos da forma como estes conceitos são empregados na academia. Se não conseguirem esse domínio da linguagem conceitual, como é que lerão Marx, por exemplo? E olhe, que direito tenho eu de lhes dizer que não precisam ler Marx porque Marx é muito difícil para eles?"25.

Para isso, uma técnica interessante é a chamada pedagogia situada. Como aponta Freire $^{26}$, "escolher temas críticos da cultura estudantil é uma opção pedagógica. Estudar assuntos acadêmicos ou formais de maneira situada é uma segunda opção, isto é, inserir a Biologia, a Enfermagem ou a Economia dentro do seu contexto social”.

Ao aprender a abstrair o concreto e situá-lo em planos mais amplos, o aluno consegue identificar a vinculação do concreto com as relações sociais que o interpenetram e o condicionam. Com base nesse conhecimento, é capaz de desenvolver uma consciência crítica da realidade. Pode-se falar, portanto, numa educação libertadora, no sentido de que o aluno se

\footnotetext{
${ }^{23}$ WEFFORT, Francisco. Prefácio. In: FREIRE, Paulo. A educação como prática da liberdade. 16. ed. São Paulo: Paz e Terra, 1990.

${ }^{24}$ FREIRE, Paulo; SHOR, Ira. Medo e ousadia: o cotidiano do professor. São Paulo: Paz e Terra, 2006. p. 176.

${ }^{25}$ Ibid., p. 178.

${ }^{26}$ Ibid., p. 130.
} 
liberta dos condicionamentos que o impediam de compreender sua situação de dependência o que já representa certo estágio de uma consciência de classe. Isso significa, ainda, tornar-se sujeito da própria educação. A categoria sujeito se abastece da de pessoa, que é muito desenvolvida pelo cristianismo, no sentido de serem pessoas e, portanto, em princípio, iguais, todos os filhos do mesmo Pai. Trata-se também de uma noção apropriada pelos humanistas. Pessoa é "ser de relações [...] capaz de transcender, de discernir [com] consciência de sua temporalidade", segundo Jardilino ${ }^{27}$. Desse aprendizado resulta uma disposição em transformar a realidade. Impossível, portanto, desvincular a educação da política.

Nesse momento o educando já alcançou aquilo que a pedagogia freireana considera a consciência transitiva. Nas palavras de Mizukami, "é uma forma crítica de pensar, pois que busca identificar e compreender os motivos e procedimentos pelos quais a representação do real de um país é produzido [...]. Interessa-se em descobrir os determinantes de seu conteúdo, pois sabe que eles existem, e tem por tarefa lógica distingui-los e avaliá-los" ${ }^{28}$. Os estágios anteriores - aqueles que devem ser superados - são a consciência intransitiva e a consciência transitiva ingênua. A primeira se caracteriza por preocupações do indivíduo circunscritas ao que nele há de vital e às quais falta historicidade. Não percebendo a maioria das relações de causa e efeito das ações humanas, tende a dar aos fenômenos explicações mágicas. Sob o domínio da segunda, o homem percebe as misérias da vida, mas se recusa a qualquer atitude que possa mudá-la, absolutizando essa situação como paradigma. É um comportamento comumente chamado de reacionário.

Já se viu que o foco principal da pedagogia de Freire é o trabalhador assalariado, visto pela análise marxiana como oprimido pelo modo de produção capitalista. Ao se submeter à educação libertadora, esse oprimido alienado traz uma estrutura de pensamento condicionada pela situação concreta de sua vida, o que resulta em consequências tais como: o ideal de ser mais homem é ser opressor; ele assume uma atitude de aderência ao opressor e quer imitá-lo; não sente confiança em si mesmo e mantém uma crença mágica no opressor; assim não consegue vê-lo fora de si. Essa aderência ao opressor o impede de ter consciência de si mesmo como pessoa, nem a consciência de classe oprimida.

Ao se libertar dessa estrutura, o oprimido passa a conhecer os mecanismos de sua opressão, torna-se crítico e capaz de optar pela transformação. $O$ acúmulo de saberes que lhe possibilitou essa nova postura é algo em constante movimento. "O saber se dá através de uma superação constante. O saber superado já é uma ignorância. Todo saber humano tem em si o testemunho do novo saber que já anuncia" ${ }^{29}$.

\section{CONCLUSÕES}

A Argentina está efetivamente aplicando a lei penal aos seus torturadores. Tendo emergido de um período ditatorial mais curto que o nosso, porém mais arrasador no que toca aos direitos humanos, conseguiu superar uma fase de acomodação servil ao militarismo e alcançar nível de verdadeira emancipação política e jurídica. Essa emancipação se expressa no enfrentamento, sem vacilação, da terrível realidade provocada pela ação do chamado

\footnotetext{
${ }^{27}$ JARDILINO, José Rubens Lima; NOSELLA, Paolo (Org.) Os professores não erram. São Paulo: Terras do Sonhar/Edições Pulsar, 2005, p. 106.

${ }^{28}$ Op. cit., p. 93.

${ }^{29}$ FREIRE, Paulo. Pedagogia da autonomia. São Paulo: Paz e Terra, 1997, p. 56.
} 
terrorismo de Estado, que vitimou quase trinta mil pessoas, entre mortos, torturados e desaparecidos. Após um período em que vigeram leis que anistiavam tais criminosos, quando não os isentavam de responsabilidade sob o manto do cumprimento de ordem superior, aquele país deu um salto de amadurecimento ao decidir aplicar o direito a quem praticara delitos, simplesmente como se usa fazer com qualquer delinquente. Revogou as leis espúrias e, considerando os delitos praticados como crimes contra a humanidade e, portanto, insuscetíveis de anistia ou prescrição, passou a processar regularmente - e a condenar - os agentes da repressão política ilegal.

Ao optar por fazê-lo, liberta-se daquela aderência ao opressor de que se falou no capítulo anterior. Seu povo e suas instituições, notadamente o Ministério Público e os Poderes Executivo, Legislativo e Judiciário, creem em si mesmos, não mais almejam a imitação do opressor e nele deixaram de acreditar. Por força desse aprendizado, revogaram as leis tendentes a impedir, ou dificultar, a responsabilização penal dos torturadores e assumiram que estes praticaram crimes contra a humanidade, não podendo, portanto, fazer jus aos benefícios da anistia ou da prescrição. Por meio de um processo de educação que evidenciou seu caráter político, na esteira da afirmação de Paulo Freire, lograram alcançar uma consciência crítica e se colocaram na posição de sujeitos da sua história, dando a ela o seguimento que só poderia ter: a assunção do papel terrorista do Estado no período da ditadura e o imperativo de realizar a justiça como único caminho para a paz política.

Não é possível a um educador argentino engajado ignorar a dimensão educativa do processo político e jurídico que conduziu à punição dos repressores como fato natural e cotidiano. No evento denominado I Seminario Internacional Paulo Freire, realizado em Buenos Aires no ano de 2013, essa simbiose ficou visível, sendo significativo que cada participante argentino que usou da palavra, sem exceção, frisou o reencontro do Estado com a nação a partir da apuração dos crimes e aplicação de pena aos infratores. Desfez-se, com isso, a sombra que turvava a busca do país por um estado de normalidade, aflorando a falsidade de uma paz que convivesse com o esquecimento, ainda que este pudesse trazer benefício econômico ou aparente segurança jurídica para os agentes do processo econômico do país.

Isso é Paulo Freire puro. Pode-se dizer que através da técnica da pedagogia situada, a nação e suas instituições tomaram o conjunto das atrocidades cometidas pelo terrorismo de Estado como objeto de conhecimento, colocaram-se à distância para melhor observá-lo e, enfim, situando-o em planos mais amplos, conseguiram identificar a vinculação do concreto com as relações sociais que o interpenetravam e o condicionavam, daí emergindo para uma consciência crítica, capaz de gerar a visão serena do fenômeno, livre das amarras que os prendiam, como observadores, ao opressor. Cresceram com esse processo, tornaram-se adultos e ostentam, por isso, um grau de maturidade política superior, resultado inequívoco de uma educação verdadeiramente emancipadora.

\section{REFERÊNCIAS}

ARGENTINA. "Lei Ponto Final" (Lei 23.492/86), "Lei Obediência Devida" (Lei 23.521/87). ASAMBLEA PERMANENTE POR LOS DERECHOS HUMANOS. Memoria y dictadura. Buenos Aires: Instituto Espacio para la Memoria, s/d.

BAYER, Osvaldo et al. El terrorismo de estado en la Argentina. Buenos Aires: Instituto Espacio para la Memoria, 2010.

Baldosas X La memoria/Barrios X Memoria y Justicia. Buenos Aires: Instituto Espacio para la Memoria, 2010, v. I e II. 
BRASIL. Decreto $n^{\circ}$ 4.388, de 25 de setembro de 2002 (promulga o Estatuto de Roma do Tribunal Penal Internacional).

BUFFA, Ester; NOSELLA, Paolo. A educação negada. São Paulo: Cortez, 2001.

CAREAGA. Ana Maria. Leyes: principales instrumentos legales sobre derechos humanos y memoria. Buenos Aires: Instituto Espacio para la Memoria, 2009.

CORTE INTERAMERICANA DE DIREITOS HUMANOS. http://www.corteidh.or.cr/docs/casos/articulos/seriec 219 por.pdf

DIARIO DEL 24 DE MARZO. Buenos Aires: Instituto Espacio para la Memoria, mar./2013. FERNANDES, Camila Vicenci. Leis de Anistia: Aspectos teóricos e as experiências da Argentina, Uruguai e $\quad$ Brasil. Em http://www.ambitojuridico.com.br/site/index.php?n_link=revista_artigos_leitura\&artigo_id=7 $\underline{637}$

FREIRE, Paulo. Pedagogia da autonomia. São Paulo: Paz e Terra, 1996.

Pedagogia do oprimido. Rio de Janeiro: Paz e Terra, 1975.

FREIRE, Paulo; SHOR, Ira. Medo e ousadia: o cotidiano do professor. Rio de Janeiro: Paz e Terra, 1986.

GENTIL, Plínio. Lei da Anistia: torturadores pedem carona. Direito e Sociedade: Revista de estudos jurídicos e interdisciplinares. Catanduva: Faculdades Integradas Padre Albino, Curso de Direito, v. 7, n. 1 (jan./dez/2012, p. 30-40).

JARDILINO, José Rubens Lima; NOSELLA, Paolo (Org.) Os professores não erram. São Paulo: Terras do Sonhar/Edições Pulsar, 2005.

MANACORDA, Mario Alighiero. História da educação. São Paulo: Cortez, 2004.

MÉNDEZ, José Luis Méndez. La operación Cóndor en Cuba. Buenos Aires: Instituto Espacio para la Memoria, 2011.

MIZUKAMI, Maria da Graça Nicoletti. Ensino: as abordagens do processo. São Paulo: EPU, 1986.

TRINDADE, Antônio Augusto Cançado. O fim das "leis" de auto-anistia. Correio Braziliense. Brasília, 18/dez/2006, Suplemento Direito\&Justiça.

http://es.wikipedia.org/wiki/D\%C3\%ADa_Nacional_de_la_Memoria_por_la_Verdad_y_la_J usticia

http://wwwpordentroemrosa.blogspot.com.br/2013/05/quando-o-presidente-da-argentinanestor.html

http://pt.wikipedia.org/wiki/Lei de Seguran\%C3\%A7a Nacional.

http://www.cineplayers.com/filme.php?id=15451

http://www.stf.jus.br/portal/geral/verPdfPaginado.asp?id=612960\&tipo=AC\&descricao=Intei ro\%20Teor\%20ADPF\%20/\%20153

http://www.dji.com.br/decretos/2002-004388/2002-004388.htm

http://es.wikipedia.org/wiki/Carta_de_Londres 